\title{
Community Use Zone (CUZ) Model and Its Outcome in Malaysia Case Study from Crocker Range Park, Sabah
}

\author{
Peter Voo ${ }^{1}$, Abrar J. Mohammed ${ }^{2} \&$ Makoto Inoue $^{2}$ \\ ${ }^{1}$ Faculty of Psychology and Education, Universiti Malaysia Sabah, Malaysia \\ ${ }^{2}$ Graduate School of Agriculture and Life Sciences, The University of Tokyo, Tokyo, Japan \\ Correspondence: Peter Voo, Faculty of Psychology and Education, Universiti Malaysia Sabah, Kota Kinabalu, \\ Sabah, Malaysia. E-mail: peter@ums.edu.my
}

Received: June 12, 2016

Accepted: July 2, 2016 Online Published: August 29, 2016

doi:10.5539/jms.v6n3p25

URL: http://dx.doi.org/10.5539/jms.v6n3p25

\begin{abstract}
The Sabah Parks has been experimenting with a new approach to forest governance, namely Community Use Zone (CUZ), in order to safeguard the forests from ongoing degradation while simultaneously providing opportunities for the affected communities to improve their living conditions and livelihoods. Despite the ongoing discourse to expand this approach, there is limited systematic study to understand the changes in governance as well as linking it to forest and livelihood outcomes. By conducting structured and semi-structured questionnaire interview to CUZ and non-CUZ community members as well as Crocker Range Park staffs, this study clarifies the changes in involvement of local people in rule making and implementation of diverse forest management activities and governance decisions as well as forest and livelihood outcomes from CUZ. The result showed that local people participation in rule making and implementation is enhanced after implementation of CUZ. While the forest outcome remains mixed, the CUZ has brought positive impact to the livelihood of the participants. CUZ also has positive externality to neighboring community in terms of their attitude towards the program.
\end{abstract}

Keywords: CUZ, forest governance, community participation, livelihood change, forest conservation, Malaysia

\section{Introduction}

Worldwide, marginalized forest communities, mostly lacking the most elementary trappings of modern development, are among the most disadvantaged and underprivileged groups of people. Frequently comprising indigenous people who are outside the mainstream of national economic and social life, they often live at a subsistence level that would be unacceptable to other rural and urban dwellers alike (Hayes, 2006). Assessed in terms of assets or incomes they often live in extreme poverty (Gassner \& Noor, 2007; Voo \& Inoue, 2015). For many such groups, the forests are crucial in enabling them to meet some or all of their basic needs through provision of goods such as fuelwood and timber (Mohammed \& Inoue, 2013). Their less environmental destructive activities, although commonly regarded as unproductive, has enabled both the people and the forest survive together for centuries (Gray, 2002). Yet, despite having an important role in the conservation of natural resources, these groups encounter problems in preserving their lifestyles and maintaining access to the forests because of in appropriate policies (Larson, 2005; Barry, Larson, \& Colfer, 2010).

Malaysia provides a good example of this stress faced by indigenous people. Although the country has progressed forward in improving the GDP as well as HDI in the last decades, the benefit of this economic growth is seldom evenly distributed across the population (EC-UNDP, 2007). On the peninsula, the east coast and northern states, especially agriculture sector, relatively sparsely populated and predominantly Malay states, have experienced limited growth. One of these states is the Sabah state. About 4.45 million hectares or 60 percent of Sabah is currently under forest cover. In the previous decades, the government of Malaysia emphasized in liquidating the forest to earn incomes. Consequently, forests become an important source of revenue for the state, contributing in excess of 50 percent of the state total from the 1970s through to theearly 1990s. In 2006, the total forest revenue was RM505 million, contributing 22.3 percent of Sabah's total revenue, and generating about 47,200 jobs (Kwok, 2007). This heavy reliance on forests to contribute to the welfare and development of the state has resulted in about 93 percent of the forest being removed or converted to secondary forest. Local people that have depended on the forest for their livelihood were left with nothing but degraded land. Recently, the 
government designated the considerably diminished tropical forests of Sabah as national protected areas (EC-UNDP, 2007). This again marginalized local people amplifying conflict between local people and park management (Inoue, Shivakoti, \& Ojha, 2015).

The authority of Sabah Parks has undertaken a variety of measures including introduction of community forestry projects to safeguard the forests from further degradation while simultaneously providing opportunities for the affected communities to improve their living conditions and livelihoods. This is also aimed at easing the ongoing conflict between local people and park management. However, integration of about 20,000 people living within forest reserves and an undetermined number on the fringes of the forest reserves into the sustainable forest management scheme is one of the major challenges for the park managers. Most of these people are defined as "hardcore poor", having little or no access to facilities that are basic and essential to daily living, and experiencing below average health and educational standards. Many are still practicing shifting cultivation to meet their daily needs (Mahanty \& Russell, 2002; Voo \& Inoue, 2015).

To address the issues of integrating people living in the forest area in to the sustainable forest management, the authority of the Sabah Parks has been experimenting with a new approach to forest governance i.e., Community Use Zone (CUZ) implemented in Crocker Range Park Sabah. Crocker Range Park, the largest protected area in Sabah, still holds a large tract of montane forests. It is a home for wildlife and traditional communities, which provides both natural significance and cultural heritage. The Crocker Range Park Management Plan was prepared in 2006 by the authority of the parks with technical assistance from The Bornean Biodiversity and Ecosystems Conservation Programmed (BBEC) Phase I (2002-2007) (Miki, Laban, Maidin, Adlin, \& Lakim, 2014). The plan introduced the concept of CUZ as a management option to address the issues concerning local communities living and utilizing resources within protected areas. CUZs are intended to be collaboratively managed by Sabah Parks and such local communities (Virtanen, 2005; Voo \& Inoue, 2015).

CUZ is defined by the authority of Sabah Parks as "areas where existing cultivation and forest resource collection are found to occur inside the Parks and where traditional human activities are allowed to continue under the supervision of the Parks Authority". The objectives of such prescribed zones are to balance the existing local communities' needs and conservation, encourage participation of and collaboration with the local communities in Park management, and protect the cultures and traditional knowledge of the local communities (Blouch, 2010; Miki et al., 2014). The CUZs legalize community access to resource areas within the Park and provide avenues for local community participation. The legal framework for the establishment of CUZs was approved by the State Legislative Assembly in the 2007 amendment to the Parks Enactment. Under this amendment, the authority of the park then had the mandate to zone sections of the park as CUZs for co-management (Voo \& Inoue, 2015).

Although the CUZ has been approved and its implementation has been undergoing, how the CUZ has integrated local people into the forest governance decisions and management activities is not clarified. Moreover, the effectiveness of the program in addressing the problem of deforestation and forest degradation is not well understood. This study aims to fill the aforesaid gap by documenting the change in forest governance in terms of participating local people in salient decisions and forest and livelihood outcome from the CUZ implementation. The study is important not only to fill the knowledge gap on CUZ implementation and effectiveness, but also because of its relevance for the ongoing policy discourse to expand implementation of CUZ model to other parks and forest reserved.

\section{Research Method}

\subsection{Study Site Description}

The study was conducted in Ulu Senagang village and Ulu Papar village. The Ulu Senagang village was selected as a representative of the villages where CUZ approach is implemented. The Ulu Papar village is selected as a control to evaluate whether the change in governance due to CUZ had impact on local people perception of the purpose of the forest. In addition, the village is also used to evaluate the perception of the villagers on the potential of CUZ for conservation and livelihood. The Ulu Senagang has 43 households with a total population of 380. It is located in the southern part of Crocker Range Park (Figure 1). The main source of income for the villagers is shifting cultivation. Currently, they occupy about 187 ha inside the forest. The Ulu Papar village is located in the Northern part of Crocker Range Park (Figure 1). It has about 200 households with a total population of about 1,700. The main ethnic group is Dusun and the main sources of income for the villagers are shifting cultivation, rubber tapping, hunting and government salary. They currently occupy an area of 2,700 ha. 


\subsection{Data Collection and Analysis}

Data was collected by key informant interview, semi-structured and structured questionnaire survey and direct observation. The key informant interview was undertaken with park staffs who were involved in implementing the CUZ model. The purpose of the interview was to understand the changes in forest management and governance after the implementation of CUZ. The semi-structured and structured questionnaire surveys were conducted to randomly selected 50 local people living in the Crocker Range Park. In order to capture the perception of both those involved in the program and those not involved in the program, 25 interviewees were randomly selected from each Ulu Senagang village (CUZ implementing village) and Ulu Papar village (not CUZ implementing village). The data was analyzed descriptively.

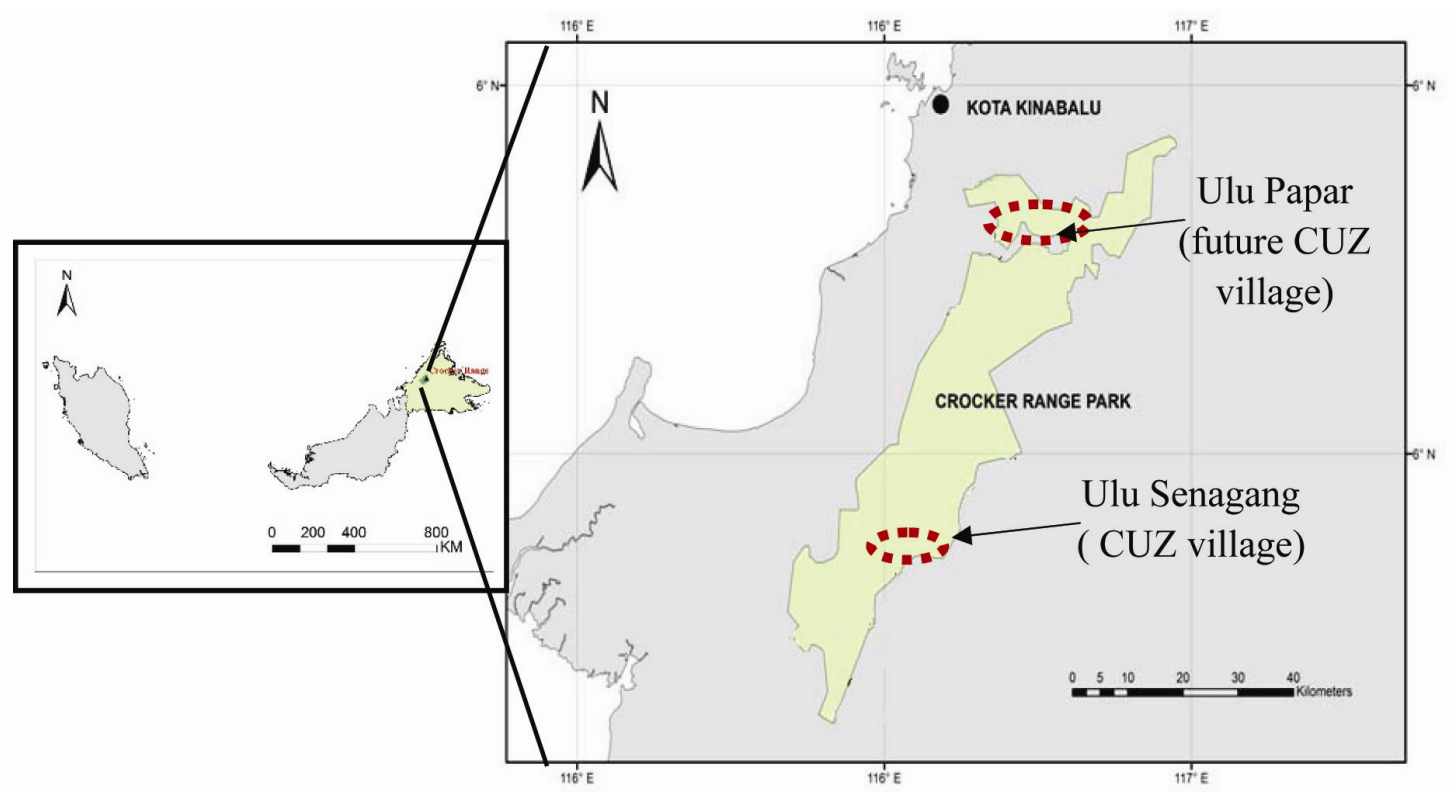

Figure 1. Location of Sabah state in Malaysia (left) and location of Croker Range Park and the study villages (right)

\section{Result}

\subsection{Change in Forest Management and Governance}

Before the implementation of CUZ, Sabah Park officers were the main actors of policy making and implementation in relation to forest maintenance activities, monitoring forest condition, monitoring local people conformance to the park rule, sanctioning rule breakers and arbitrating conflict within local communities. There were no rules or activities in relation to forest harvest, utilization and benefit sharing to and among local people (Table 1). After the implementation of CUZ, local community involvement in the governance and management of the special utilization zone has improved. The community autonomously makes and implements rule regarding how much and when to harvest forest product in the CUZ area. They also make rule, together with Sabah park officers, regarding what forest product to harvest, what harvesting technology to use, how to sanction rule breakers and how to arbitrate conflict with in the community. Rules on how to monitor the condition of CUZ and rule conformity of the community as well as forest maintenance is undertaken by the Sabah park officers (Table 1). 
Table 1. Changes in forest management and governance after the implementation of CUZ

\begin{tabular}{lllll}
\hline Activity & \multicolumn{2}{c}{$\begin{array}{c}\text { Before CUZ } \\
\text { Make rule }\end{array}$} & $\begin{array}{c}\text { Amplement } \\
\text { ImUZ }\end{array}$ & $\begin{array}{l}\text { Make rule } \\
\text { Implement }\end{array}$ \\
\hline Forest maintenance & SP & SP & SP & SP and CM \\
Harvest Forest Products & - & - & SP and CM & CM \\
Determine timing (season) of the harvest of forest products & - & - & CM & CM \\
Determine quantity of harvested forest products & - & - & CM & CM \\
Determine type of technology used to harvest forest products & - & - & SP and CM & SP \\
Determine who is authorized to harvest forest products & - & - & CM. & CM \\
Monitor forest condition & SP & SP & SP & SP and CM \\
Monitor conformance to rules & SP & SP & SP & SP \\
Sanction rule breakers (e.g., fines) & SP & SP & SP and CM & SP \\
Arbitrate disputes among local users & SP & SP & SP and CM & SP and CM \\
\hline
\end{tabular}

Note. SP: Sabah Park officers. CM: CUZ community.

\subsection{Function of the Forest}

In collaborative forest management, one of the important steps is to narrow the interest gap among the collaborating actors with respect to the objective and outcome of the action they are collaborating on. Hence, we checked the perception of the three key stakeholders, or people currently implementing CUZ, local community living in the forest but not included in the CUZ (nCUZ hereafter) and Sabah park officers, to see if implementation of CUZ had an impact on perception of the purpose of the forest. We found that watershed, recreational value, biodiversity protection and carbon sequestration respectively to be the four important function of the forest for CUZ community while then CUZ community ranked watershed and biodiversity to be the most important followed by carbon sequestration, recreational value and provision of non-timber forest product. Interestingly, none of the communities, both CUZ and nCUZ, mentioned source for timber related product as the main purpose of forest. For park officers, although biodiversity conservation, recreational value and watershed accounted for the top three important services of the forest, timber production and agroforestry were also mentioned as vital purposed of the forest (Table 2). In general, however, we found strong correlation among the three stakeholders in their ranking of the purpose of the forest, the strongest being between CUZ members and nCUZ community $(\rho=0.84, p=0.0096)$, followed by between Sabah park officers and nCUZ community $(\rho=0.77$, $\mathrm{p}=0.0258)$ and between Sabah park officers and CUZ community $(\rho=0.66, \mathrm{p}=0.0662)$.

Table 2. Interest of different stake holders on diverse forest goods and services

\begin{tabular}{llll}
\hline Purpose of the Forest & CUZ & nCUZ & Staffs \\
\hline Biodiversity protection & 4.2 & 4.7 & 5.0 \\
Fuelwood source & 3 & 1.0 & 1.7 \\
Watershed & 4.5 & 4.7 & 3.7 \\
Timber production & 1.8 & 1.0 & 3.3 \\
Carbon sequestration & 3.7 & 4.3 & 1.3 \\
Agroforestry & 2.7 & 1.7 & 4.0 \\
Non timber forest products & 3.2 & 3.7 & 1.7 \\
Recreational value & 4.3 & 3.7 & 4 \\
\hline
\end{tabular}

Note. CUZ: CUZ implementing village, nCUZ: nearby village not implementing CUZ.

\subsection{Change in Forest Outcome}

Although CUZ is implemented to minimize pressure on the forest, its important impact on the forest, according to the participants, is on the size of the forest with $92 \%$ of the interviewees informing some extent increase in the forest size. However, the species diversity remained the same (96\%) while thevegetation density either declined $(56 \%)$ or remained the same (28\%) (Table 3). According to the nCUZ interviewees, CUZ would mainly contribute to conservation of the existing forest, with $60 \%, 44 \%$ and $96 \%$ mentioning the density, species diversity and area of the forest respectively would remain the same (Table 3). The reasons they mentioned are: the forest will be better guarded by locals as they will be allowed to get wood and forest resources for medications; community will not cut down trees indiscriminately because there will be CUZ rules and monitoring; implementation of CUZ will protect the extinction of flora and fauna; CUZ will minimize 
exploration activities, illegal hunting and poaching.

Table 3. Community Utilization Zone program members (CUZ) and non-members (nCUZ) perception on change in forest condition after CUZ implementation (\% of interviewees)

\begin{tabular}{llllll}
\hline Rank & Density of Vegetation & \multicolumn{2}{c}{ Species Diversity } & \multicolumn{2}{c}{ Area of the Forest } \\
& CUZ & nCUZ & CUZ & nCUZ & CUZ \\
\hline Increased significantly & 4 & 4 & 4 & 0 & 4 \\
Somehow increased & 8 & 24 & 0 & 40 & 92 \\
Remained the same & 28 & 60 & 96 & 4 & 4 \\
Somehow Decreased & 56 & 12 & 0 & 0 & 0 \\
Decreased significantly & 4 & 0 & 0 & 0 & 0 \\
\hline
\end{tabular}

\subsection{Changes in the Forest's Livelihood Contribution}

For most of the participant of CUZ program, the subsistence value of the forest somehow increased (92\%). The overall livelihood of the participants also improved $(68 \%)$ as did the direct contribution of the forest for their livelihood (64\%) (Table 4). For the nCUZ villagers, however, they perceived that the subsistence value of the forest would remain the same $(100 \%)$ as will the direct livelihood contribution of the forest $(72 \%)$ while $84 \%$ of the respondents mentioned that their overall livelihood would improve if the CUZ is implemented (Table 4). They mentioned that CUZ would help them own land that will generate income for them. Some also mentioned their current location which is inside the forest, will be legally recognized if CUZ is implemented, liberating them from risk of evacuation. Interestingly, some of the interviewees admitted that their current settlement is inside the park and belongs to the park. They also mentioned that if CUZ is implemented and they become legalized, their welfare would get much better attention by different external agencies including the government.

Table 4. Community Utilization Zone program members (CUZ) and non-members (nCUZ) perception on livelihood contribution of CUZ implementation (\% of interviewees)

\begin{tabular}{lllllll}
\hline Rank & \multicolumn{2}{l}{ Subsistence value of the forest } & \multicolumn{2}{l}{ Overall Livelihood } & \multicolumn{2}{c}{ Direct Livelihood contribution of the forest } \\
& CUZ & nCUZ & CUZ & nCUZ & CUZ & nCUZ \\
\hline Increased significantly & 0 & 0 & 4 & 0 & 0 & 0 \\
Somehow increased & 92 & 0 & 68 & 84 & 64 & 28 \\
Remained the same & 8 & 100 & 28 & 16 & 36 & 0 \\
Somehow Decreased & 0 & 0 & 0 & 0 & 0 & 0 \\
Decreased significantly & 0 & 0 & 0 & 0 & 0 & 0 \\
\hline
\end{tabular}

\section{Discussion}

Protected areas such as the Crocker Range Park play an important role in conserving tropical biodiversity and ecosystems services. The Crocker Range Park is a home for more than 737 plant species, 101 mammals, 259 birds, 47 reptiles, 63 amphibians, and 42 freshwater fishspecies. Two endemic Rafflesia species are also found in the Crocker Range Park. In addition to being a significant biodiversity site, the Park is also an important water catchment area as the sources of 12 major rivers. The Crocker Range is also the habitat of several endangered species such as the Orangutan (Pongo pygmaeus), the sun bear (Helarctos malayanus), and the clouded leopard (UNESCO, 2014).

Policies concerning protected areas have changed considerably over time, from classic, scientific and exclusionary approaches to more human-centered models (Mannigel, 2008). The story of CUZ in the Crocker Range Park is no different. Prior to CUZ implementation in the Crocker Range Park, the governance system of the Park was top down governance approach where local people were forced to abide by the restrictive rules of the state. Such centralized forest governance has for long time marginalized local people from the forest. The people living inside the Crocker Range Park generally have relatively low productive assets. Hence, restriction of access to and rights over productive natural resources such as forest constitutes an additional major burden to the already low life standard of the community. Collaborative Forest Management (CFM) which is a working partnership between local communities and external actors is aimed at integrating local people into a forest governance decision-making that affects their livelihood (World Bank, 1999; Carter \& Gronow, 2005; Kothari, Camill, \& Brown, 2013; Akamania \& Hallb, 2015, Mohammed \& Inoue, 2014a; Inoue et al., 2015). In most 
cases, as in the CUZ model, it involves government's agents (Sabah park staffs) and local people that derive direct benefit from the forest (CUZ communities) (Castro \& Nielsen, 2001; Carlsson \& Berkes, 2005, Mohammed \& Inoue, 2014a). The implementation of CUZ involved allocating land for cultivation and utilization inside protected area which is similar to the implementation of Hutan Kemasyarakatan (HKm) in protection forest of Indonesia (Kaskoyo, Mohammed, \& Inoue, 2014).

The central feature of all effective CFM approaches is sharing decision-making and responsibilities over the management of forests among the government agents and forest users (Carter \& Gronow, 2005; Mohammed \& Inoue, 2012). The complex and dynamic nature of environmental problems requires flexible and transparent decision-making that embraces a diversity of knowledge and values (Reed, 2008). In the case of the Crocker Range Park, after the implementation of CUZ, forest governance and management activities regarding harvest of forest product, sanctioning rule breakers and arbitrate conflict is done by local communities and park staffs. This is intended to strengthen the management and governance of the Crocker Range Park. As argued by many scholars including Fisher (1995); Carter \& Gronow (2005); Carlsson \& Berkes (2005); Mahanty \& Russell (2009); Kothari et al. (2013); Akamani \& Helb (2015), CFM is an appealing arrangement for sustainable SESs because of its potential to combine strengths of different management approaches.

Implementation of CFM is expected to bring common ground for exiting pluralism to the purpose of the forest governance by bridging gaps and accommodating diverse interests. Pluralism describes a situations where distinct groups such as CUZ communities and Sabah Park that are actively autonomous and independent, but often interdependent, with legitimate claims and different positions on critical substantive issues. These differences are based on separate values, perceptions, objectives and knowledge (Anderson, Clément, \& Crowder, 1998). Interestingly in our study, we found higher correlation on type of interest on the forest between nCUZ villagers and Sabah park staffs as compared to CUZ community and Sabah park staffs. Hence it is difficult to claim that the implementation of CUZ has brought change to moderating diverse interest on the forest.

CFM is promoted embracing the philosophy of forest conservation and livelihood improvement through cooperation between the two stakeholders (Bhattacharya, Pradhan, \& Yadav, 2010). In the case of CUZ; the outcome is mixed. Most of the respondents mentioned that the CFM only improved forest area while forest density declined and species diversity remained the same. The reasons for the increase in area of the forest are the increase in area demarcated as forest as well as legalization of use right in the CUZ area for agriculture which minimized boundary encroachment. However, the density of the core forest has declined because of consumption of resources by the community for their own subsistence use and intrusion from resident outside of CUZ.

On the other hand, respondent mentioned that the CFM arrangement has contributed positively for their livelihood. The reason for improvement in subsistence value as well as direct livelihood contribution of the forest is the permission to cultivate inside the CUZ land given by the Park that allowed the participant to undertake diversified farming. They can now successfully grow agricultural products such as rubber, cocoa and fruits trees in their CUZ farmland. The overall livelihood improvement after CUZ, in addition to being allowed to farm in the CUZ land, is also because of getting guidance from Sabah park staffs on making handicrafts and utilization of better farming technic and procedure in the CUZ area. This has diversified the source of income for the members.

Our findings on forest and livelihood outcome from CUZ is similar to previous study by Mohammed et al. (2016) that showed improvement in forest and livelihood outcome from implementation of CFM in Philippines and Bangladesh. However, other studies have shown CFM to benefit the forest but harm local people. For example, in their study in Uganda, Turyahabwe and his colleagues reported that compartments under CFM had more live stems of both timber and pole tree species, more trees with harvestable logs and significantly higher merchantable volume as compared to non-CFM compartments because of FDs role in monitoring harvesting rules of local communities). Nonetheless, the strict restriction of the FD resulted in decline of Forest Users' livelihood (Turyahabwe, Tumusiime, Byakagaba, \& Tumwebaze, 2013). Hence, in what governance and management setting CFM leads to synergy outcome requires further investigation. Moreover, whether CUZ and similar models will be sustainable depends on future demography of the community residing inside the forest. Population increase may intensify demand for agriculture land and force expansion of agriculture into the forest (Mohammed \& Inoue, 2014b)

\section{Conclusion and Policy Implications}

This study has four major findings. The first one is the improvement of local participation in forest management and governance after the implementation of CUZ. CUZ participants and local people autonomously make and 
implement rules regarding how much and when to harvest forest product. They also make and implement together with Sabah park officers, rules regarding what forest product to harvest, what harvesting technology to use, how to sanction rule breakers and how to arbitrate conflict within the community. The second finding is that although collaborative forest management such as CUZ is expected to narrow down the gap among actors with divergent, at times conflicting, stake on the forest, we found higher correlation of purpose of the forest between non-CUZ members and Sabah park staffs as compared to CUZ community and Sabah park staffs. Hence it is difficult to claim that the implementation of CUZ has moderated divergent interest on the forest.

The third and fourth findings of the study are related to forest and livelihood outcomes. For majority of the respondent, the main positive impact of CUZ is forest area improvement while forest stocking either reduced or remained the same after the implementation of CUZ. Species diversity also remained the same after implementation of CUZ. On the other hand, the direct livelihood contribution of the forest, its subsistence value as well as overall livelihood condition of CUZ program participant improved after CUZ implementation. But for neighboring villagers who are planning to implement CUZ in the future, they perceived that CUZ would not only improve area of the forest cover but also stocking and to some level species diversity. For their livelihood, however, subsistence value as well as direct livelihood contribution of the forest would remain the same if CUZ implemented. But their overall livelihood would change for better due to special attention from the government that comes with the implementation of CUZ.

\section{Acknowledgements}

The first author is thankful to the Ministry of Education, Malaysia for supporting a one year postdoctoral stay at the University of Tokyo where this research was conducted. The data collection of this study is supported by JSPS Grant-in-Aid for Scientific Research (A) (No. 24248026, Leader: Makoto Inoue, FY2012-2015).

\section{References}

Akamani, K., \& Hall, T. E. (2015). Determinants of the process and outcomes of household participation in collaborative forest management in Ghana: A quantitative test of a community resilience model. Journal of Environmental Management, 147, 1-11. http://doi.org/10.1016/j.jenvman.2014.09.007

Anderson, J., Clément, J., \& Crowder L. V. (1998). Accommodating conflicting interests in forestry concepts emerging from pluralism. Unasylva, 194.

Barry, D., Larson, A. M., \& Colfer, C. J. (2010). Forest tenure reform: An orphan with only uncles. In A. M. Larson, D. Barry, G. R. Dahal, \& C. J. Pierce Colfer (Eds.), Forests for People (pp. 19-37). London: Earthscan.

Bhattacharya, P., Pradhan, L., \& Yadav, G. (2010). Joint forest management in India: experiences of two $\begin{array}{lllll}\text { decades. Resource } & \text { Conservation and Recycling, 54, }\end{array}$ http://doi.org/10.1016/j.resconrec.2009.10.003

Blouch, R. A. (2010). Zoning for People Within Indonesia's Kerinci Seblat National Park. Journal of Sustainable Forestry, 29, 2-4, 432-450. http://doi.org/10.1080/10549810903550852

Carlsson, L., \& Berkes, F. (2005). Co-management: concepts and methodological implications. Journal of Environmental Management, 75(1), 65-76. http://doi.org/10.1016/j.jenvman.2004.11.008

Carter, J., \& Gronow, J. (2005). Recent experience in collaborative forest management. CIFOR Occasional Paper No. 43. Bogor: CIFOR.

Castro, A. P., \& Nielsen, E. (2001). Indigenous people and co-management: implications for conflict $\begin{array}{lllll}\text { management. Environmental Science and } & \text { Policy, }\end{array}$ http://doi.org/10.1016/S1462-9011(01)00022-3

EC-UNDP. (2007). Guidelines for Facilitators of Community Forestry Projects in Malaysia, Small Grants Programme for Operations to Promote Tropical Forests, Malaysia.

Fisher, R. J. (1995). Collaborative management of forests for conservation and development. IUCN: Gland.

Gassner, A., \& Noor, M. F. (2007). Framework for an Agroforestry Based Management Plan for the Mangkuwagu Forest Reserve, Report to the Sabah Forestry Department, April.

Gray, L. C. (2002). Environmental policy, land rights, and conflict: Rethinking community natural resource management programs in Burkina Faso. Environment and Planning D: Society and Space, 20, 167-182. http://doi.org/10.1068/d256 
Inoue, M., Shivakoti, G. P., \& Ojha, H. R. (2015). Multi-level forest governance in Asia: An introduction. In M. Inoue \& G. P. Shivakoti (Eds.), Multi-level forest governance in Asia: Concepts, Challenges and the Way Forward. New Delhi, India: Sage Publication.

Kaskoyo, H., Mohammed, A. J., \& Inoue, M. (2014). Present State of Community Forestry (Hutan Kemasyarakatan/HKm) Program in a Protection Forest and Its Challenges: Case Study in Lampung Province, Indonesia. Journal of Forest Science, 30(1), 15-29. http://dx.doi.org/10.7747/JFS.2014.30.1.15

Kit, K. K. (2007). Poverty, Inequality and Welfare in Sabah, Study to Identify Strategies and Programmes to Eradicate Poverty and Improve Employment and Equity Restructuring in Sabah and Sarawak. UNDP Malaysia, unpublished.

Kothari, A., Camill, P., \& Brown, J. (2013). Conservation as if people mattered: Policy and practice of community-based conservation. Conservation and Society, 11, 1-15. http://doi.org/10.4103/0972-4923.110937

Larson, A. M. (2005). Democratic decentralization in the forestry sector: Lessons learned from Africa, Asia and Latin America. In C. J. Pierce Colfer \& D. Capistrano (Eds.), The Politics of Decentralization: Forests, People and Power (pp. 32-62). London: Earthscan.

Mahanty, S., \& Russell, D. (2002). High Stakes: Lessons from Stakeholder Groups in the Biodiversity Conservation Network. Society and Natural Resources, 15(2), 179-188. http://doi.org/10.1080/089419202753403346

Mannigel, E. (2008). Integrating parks and people: how does participation work in protected area management? Society and Natural Resources, 21(2), 498-511. http://doi.org/10.1080/08941920701618039

Miki, Y., Laban, D., Maidin, N., Adlin, T. Z., \& Lakim, M. (2014). Crocker Range Park Community Use Zone (CUZ). Paper presented at the IUCN World Parks Congress, Sydney, 12-19 November.

Mohammed, A. J., \& Inoue, M. (2012). Explaining disparity in outcome from community-based natural resource management (CBNRM): a case study in Chilimo Forest, Ethiopia. Journal of Environment Planning and Management, 55, 1248-1267. http://doi.org/10.1080/09640568.2011.640171

Mohammed, A. J., \& Inoue, M. (2013). Exploring decentralized forest management in Ethiopia using actor-power-accountability framework: case study in West Shoa zone. Environment, Development and Sustainability, 15, 807-825. http://doi.org/10.1007/s10668-012-9407-z

Mohammed, A. J., \& Inoue, M. (2014a). A Modified Actor-Power-Accountability Framework (MAPAF) for analyzing decentralized forest governance: case study from Ethiopia. Journal of Environmental Management, 139, 188-199. http://doi.org/10.1016/j.jenvman.2014.03.002

Mohammed, A. J., \& Inoue, M. (2014b). Land Tenure Reform and Its Implication for the Forest. Case Study from Oromia Regional State of Ethiopia. Journal of Forest and Environmental Science, 30(4), 393-404. http://dx.doi.org/10.7747/JFES.2014.30.4.393

Mohammed, A. J., Inoue, M., Peras, R. J., Nath, T. K., Jashimuddin, M., \& Pulhin, J. M. (2016). Transformation Strategy for Managing Coupled Socio-Ecological Systems: Case Studies from Bangladesh and the Philippines. Small Scale Forestry, 15(2), 213-227. http://doi.org/10.1007/s11842-015-9318-6

Reed, M. S. (2008). Stakeholder participation for environmental management: A literature review. Bilogical Conservation, 141(10), 2417-2431. http://doi.org/10.1016/j.biocon.2008.07.014

Ribot, J. C. (2003). Democratic decentralisation of natural resources: Institutional choice and discretionary power transfers in Sub-Saharan Africa. Public Administration and Development, 23, 53-65. http://doi.org/10.1002/pad.259

Schusler, T. M., Decker, D. J., \& Pfeffer, M. J. (2003). Social learning for collaborative natural resource management. Society and Natural Resources, 16, 309-326. http://doi.org/10.1080/08941920390178874

Turyahabwe, N., Tumusiime, D. M., Byakagaba, P., \& Tumwebaze, S. B. (2013). Impact of Collaborative Forest Management on Forest Status and Local Perceptions of Contribution to Livelihoods in Uganda. Journal of Sustainable Development, 6(10), 36-46. http://dx.doi.org/10.5539/jsd.v6n10p36

UNESCO. (2014). Ecological Sciences for Sustainable Development: Crocker Range. Retrieved from http://www.unesco.org/new/en/natural-sciences/environment/ecological-sciences/biosphere-reserves/asia-an d-the-pacific/malaysia/crocker-range/ 
Virtanen, P. (2005). Community-based natural resource management in Mozambique: A critical review of the concept's applicability at local level. Sustainable Development, 13, 1-12. http://doi.org/10.1002/sd.240

Voo, P., \& Inoue, M. (2015). Key issues in application of community use zone (CUZ) to Crocker range park from the perspective of Social Work (pp. 49-53). Paper presented at the 2nd International Conference on Agriculture and Forestry, Colombo, 10-12 June. http://doi.org/10.13140/RG.2.1.1790.4808

World Bank. (1999). Report from the International Workshop on Community-Based natural Resource Management (CBNRM). Washington DC: World Bank.

\section{Copyrights}

Copyright for this article is retained by the author(s), with first publication rights granted to the journal.

This is an open-access article distributed under the terms and conditions of the Creative Commons Attribution license (http://creativecommons.org/licenses/by/4.0/). 